\title{
Family Farmers and Water Conservation: Learning Nature-Based Solutions as Human Based Solution ${ }^{\dagger}$
}

\author{
Rita de Cassia Almeida da Costa 1,* and Azeneth Eufrausino Schuler ${ }^{2}$ \\ 1 Programa ProfAgua, Universidade do Estado do Rio de Janeiro, Rio de Janeiro 20550-900, Brazil \\ 2 Empresa Brasileira de Pesquisa Agropecuária, Embrapa Solos, Rio de Janeiro 22460-000, Brazil; \\ azeneth.schuler@embrapa.br \\ * Correspondence: ritacalmeidacosta@gmail.com \\ + Presented at TERRAenVISION 2019, Barcelona, Spain, 2-7 September 2019.
}

Published: 16 June 2020

\begin{abstract}
Bringing up conservation awareness among key stakeholders is essential for water management and it requires motivation and dialogue in order to achieve local and global environmental sustainability. Water management and agriculture must be in agreement to guarantee current and future multiple uses of water. This paper presents the role of outdoor education as a way for citizens to get involved in territory demands. This study-case of participatory monitoring of Macabu River Basin has been carried out since 2012 in Trajano de Moraes, Rio de Janeiro State, Brazil. Firstly, a bibliographic review and search of historical documents offered the basis to the project "River Macabu in action: history, knowledge and life". It was aimed at linking land use to water quality and involved students from nine different schools. The relationship between surface water and hydrologic cycle was observed through monitoring rainfall at nine pluviometers installed along $70 \mathrm{~km}$ of river length, and the water quality at eleven collection points. The project strategy focused on experiencing historical and geographic contexts and understanding the nature's goods as a heritage of affective value before endowing it with economic one. The project was triggered after the agreement of various societal segments and an effective sharing for the adequacy of different ways of execution. In the first few months the farmers' resistance to the project had been overcome as they were sensitized by relatives involved in it. After some time, most farmers got connected to territory and were able to understand the state of the river as an extension of their own choices. Then, conservation practices in agriculture became more frequent mainly in the upper part of the watershed acting as links between the urban and the rural population. The methodology developed in this project was acknowledged as a citizenship solution for water by "Market of Solutions" in the 8th World Water Forum held in 2018. The engagement of young people has been noticed in different forums such as the National Conference on Environment. The farmers' practical knowledge associated to hands-on education and effective participation in actions for water management actions were considered fundamental to the citizens' comprehension of the environmental conservation. The results showed the benefits from the farmers and their children's involvement in the management of water and territory. The participation of family farmers in the River Basin Committees is considered highly relevant to the fulfilment of their legal role as core forums of the water management.
\end{abstract}

Keywords: participatory monitoring; water management; natural heritage 
Acknowledgments: The authors thank to the Municipality of Trajano de Moraes, State of Rio de Janeiro, for help developing the project and the support of Brazilian water agency ANA-Agencia Nacional de Águas.

(C) 2020 by the authors. Licensee MDPI, Basel, Switzerland. This article is an open access article distributed under the terms and conditions of the Creative Commons Attribution (CC BY) license (http://creativecommons.org/licenses/by/4.0/). 